\title{
Modified Eremophilanes and Anti-Inflammatory Activity of Psacalium cirsiifolium
}

\author{
Amira Arciniegas, ${ }^{a}$ Ana L. Pérez-Castorena, ${ }^{*, a}$ Antonio Nieto-Camacho, ${ }^{a}$ \\ José Luis Villaseñor ${ }^{b}$ and Alfonso Romo de Vivar ${ }^{a}$
}

\author{
${ }^{a}$ Instituto de Química and ${ }^{b}$ Instituto de Biología, Universidad Nacional Autónoma de México, \\ Circuito Exterior, Ciudad Universitaria, 04510 Coyoacán, D. F., México
}

\begin{abstract}
Quatro novos eremofilanos modificados, juntamente com dez derivados conhecidos de cacalol, dois cariofilenos, um aromadendreno e um flavonoide foram purificados a partir de Psacalium cirsiifolium. As estruturas destes compostos foram elucidadas por análise espectroscópica. A atividade anti-inflamatória dos extratos e de sete dos compostos isolados foi avaliada no modelo de 12-O-tetradecanoilforbol-13-acetato (TPA) de inflamação aguda induzida. O composto inédito $2 \alpha$-hidroxiadenostin B (4) mostrou uma atividade dependente da dose $\left(\mathrm{IC}_{50} 0,41 \mu \mathrm{mol}\right.$ por orelha) e um efeito de inibição de neutrófilos medido pelo teste de mieloperoxidase (MPO) semelhante ao efeito da indometacina, 0,31 e $1,0 \mu \mathrm{mol}$ por orelha.
\end{abstract}

Four new modified eremophilanes, together with ten known cacalol derivatives, two caryophyllenes, one aromadendrene and one flavonoid were isolated from Psacalium cirsiifolium. The structures of these compounds were elucidated by spectroscopic analysis. The antiinflammatory activity of extracts and of seven of the isolated compounds was evaluated on 12-O-tetradecanoylphorbol-13-acetate (TPA) model of induced acute inflammation. The new compound $2 \alpha$-hydroxyadenostin $\mathrm{B}(4)$ showed a dose dependent activity $\left(\mathrm{IC}_{50} 0.41 \mu \mathrm{mol}\right.$ per ear) and a neutrophil inhibition effect as measured by the myeloperoxidase (MPO) assay similar to that of indomethacin at 0.31 and $1.0 \mu \mathrm{mol}$ per ear.

Keywords: Psacalium, modified eremophilanes, anti-inflammatory activity, TPA, myeloperoxidase

\section{Introduction}

Psacalium cirsiifolium is one of the 40 species of perennial herbs grouped into the genus Psacalium (Asteraceae, Senecioneae, Tussilagininae). ${ }^{1}$ They are disseminated from the south of the United States to Guatemala and some of them are used in folk medicine to cure diabetes and renal, hepatic, gastrointestinal and dermatological problems..$^{2,3}$ The hypoglycemic, anti-inflammatory and antioxidant activities of $P$. decompositum, ${ }^{4-6} P$. peltatum ${ }^{7,8}$ and $P$. radulifolium ${ }^{9}$ extracts have been reported. The antimicrobial effects of $P$. radulifolium ${ }^{10}$ and the antiinflammatory properties of $P$. sinuatum ${ }^{11}$ have also been determined. Sesquitepenes mainly of eremophilane and modified eremophilane types are the main secondary metabolites isolated from the eight species of the genus chemically studied so far: $P$. decompositum ${ }^{4-6}$ (also studied as Cacalia decomposita), ${ }^{12,13}$ P. tussilaginoides (studied

*e-mail: alperezc@unam.mx as Cacalia ampulacea), ${ }^{13} P$. peltatum,${ }^{7,8} P$. sinuatum, ${ }^{11}$ $P$. radulifolium, ${ }^{9,10} P$. paucicapitatum, ${ }^{14}$ P. megaphyllum ${ }^{15}$ and $P$. beamanii. ${ }^{16}$ Cacalol has been identified as the major active compound in these species with antioxidant, ${ }^{9}$ antimicrobial ${ }^{10}$ and anti-inflammatory ${ }^{17}$ activities. Cacalone, epi-cacalone, maturinone, and radulifolin $\mathrm{D}$ have also shown anti-inflammatory properties. ${ }^{17,18}$ As continuation of our research on Senecioneae we studied the chemical composition of $P$. cirsiifolium which to the best of our knowledge has no previous studies. We report the isolation of fourteen modified eremophilane derivatives (1-14), of which four (1-4) are described for the first time. Two known caryophyllenes (16, 18), one aromadendrene (17) and one flavonoid (15) were also isolated (Figure 1). The 12-O-tetradecanoylphorbol-13acetate (TPA) model of induced acute inflammation was used to evaluate the anti-inflammatory activity of extracts and of the isolated compounds non-evaluated previously. The most active compound (4) was tested on the myeloperoxidase (MPO) assay to determine its effect on the recruitment of inflammatory cells, such as neutrophils. 


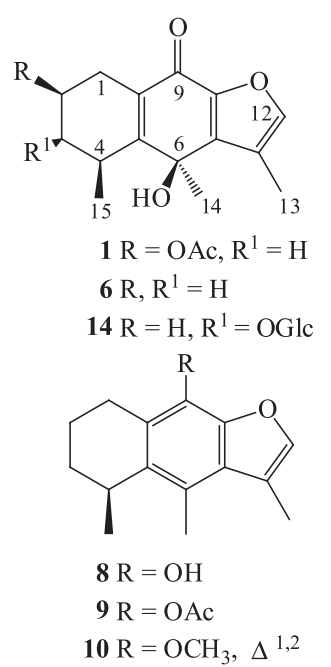<smiles>[R]C1([R])c2c(C)coc2C(=O)c2ccc(O)c(C)c21</smiles>

$12 \mathrm{R}=\mathrm{CH}_{3}, \mathrm{R}^{1}=\mathrm{H}$ $13 \mathrm{R}=\mathrm{CH}_{3}, \mathrm{R}^{1}=\mathrm{OH}$

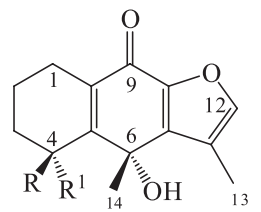

$2 \mathrm{R}=\mathrm{OH}, \mathrm{R}^{1}=\mathrm{CH}_{3}$

$3 \mathrm{R}=\mathrm{CH}_{3}, \mathrm{R}^{1}=\mathrm{OH}$

$5 \mathrm{R}=\mathrm{CH}_{3}, \mathrm{R}^{1}=\mathrm{H}$

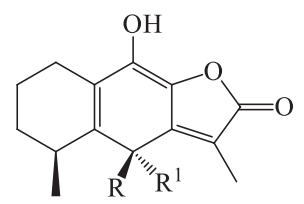

$11 \mathrm{R}=\mathrm{CH}_{3}, \mathrm{R}^{1}=\mathrm{OH}$ $\mathrm{R}=\mathrm{OH}, \mathrm{R}^{1}=\mathrm{CH}_{3}$

$\mathrm{HO}$<smiles></smiles>

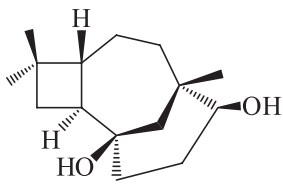

18

Figure 1. Chemical structures of compounds 1-18.

\section{Results and Discussion}

Compound 1 was obtained as a colorless oil. The IR spectrum indicated hydroxyl, ester and conjugated ketone groups $\left(3390,1743,1661 \mathrm{~cm}^{-1}\right)$. The molecular formula $\mathrm{C}_{17} \mathrm{H}_{20} \mathrm{O}_{5}$, determined by HRESIMS, showed eight degrees of insaturation. The ${ }^{1} \mathrm{H}$ NMR spectrum (Table 1) was similar to those of cacalone (5) and epi-cacalone $(\mathbf{6})^{6}$ with two additional signals at $\delta_{\mathrm{H}} 5.13(\mathrm{tt}, 1 \mathrm{H}, J 6.0,5.0 \mathrm{~Hz}$ ) and $2.05(\mathrm{~s}, 3 \mathrm{H})$. The first one was attributed to $\mathrm{H}-2$ by its correlations with the $\mathrm{H}_{2}-1$ and $\mathrm{H}_{2}-3$ methylene groups observed in the COSY experiment. The downfield chemical shift of H-2 indicated that an acetate group, whose methyl group appeared at $\delta_{\mathrm{H}} 2.05$ was attached to this position, and, in addition, $\mathrm{H}-2$ showed an interaction with the carbonyl at $\delta_{\mathrm{C}} 170.5$ in the HMBC experiment. The NOESY spectrum showed interactions between $\mathrm{H}_{3}-15$ and the acetate methyl, therefore this group should have a $\beta$-pseudoaxial orientation, since on biogenetic grounds $\mathrm{H}_{3}-15$ is $\beta .{ }^{19}$ Likewise, the coupling constant of $\mathrm{H}-2(J 6.0,5.0 \mathrm{~Hz})$ suggested its $\alpha$-pseudoequatorial orientation. Moreover, a $\mathrm{CD}$ (circular dichroism) analysis of compound $\mathbf{1}$ showed a similar profile to that of epi-cacalone (6), consequently, the hydroxyl group at C-6 $\left(\delta_{\mathrm{C}} 72.1\right)$ in $\mathbf{1}$ should be $\beta$-oriented as the one in $\mathbf{6}$. Therefore, 1 was identified as $(2 R, 4 S, 6 S)$ 2-acetoxy-epi-cacalone.

Compounds 2 and $\mathbf{3}$ exhibited the same molecular formula $\mathrm{C}_{15} \mathrm{H}_{18} \mathrm{O}_{4}$ (HRESIMS) and very similar spectroscopic data, with evidence of hydroxyl $\left(3400 \mathrm{~cm}^{-1}\right)$ and conjugated carbonyl groups $\left(1660 \mathrm{~cm}^{-1}\right)$ in the IR spectra. The ${ }^{1} \mathrm{H}$ and ${ }^{13} \mathrm{C}$ NMR spectroscopic data of these compounds also resembled those of cacalone (5) and epi-cacalone (6), ${ }^{6}$ and were indicative of the presence of an additional hydroxyl group. Position of this additional group at C-4 $\left(\delta_{\mathrm{C}} 75.5\right.$ in 2 and 74.6 in 3 ) was supported by the correlations observed in the HMBC experiments between $\mathrm{H}_{3}-15$ and $\mathrm{C}-4$ in both 2 and 3 . Differences between the two compounds were however observed in their ${ }^{1} \mathrm{H}$ NMR spectra (Table 1) where methyl groups 14 and 15 appeared at $\delta_{\mathrm{H}} 1.91(\mathrm{~s}, \mathrm{H}-14)$ and $1.70(\mathrm{~s}, \mathrm{H}-15)$ in compound 2, and at $\delta_{\mathrm{H}} 1.85(\mathrm{~s}, \mathrm{H}-14)$ and $1.59(\mathrm{~s}, \mathrm{H}-15)$ in $\mathbf{3}$; and in the ${ }^{13} \mathrm{C}$ NMR spectrum of $\mathbf{2}$ (Table 2), the signals of C-14 and C-15 appeared at $\delta_{\mathrm{C}} 28.5$ and 29.6, respectively, while in compound $\mathbf{3}$ the signals of the same atoms were observed at $\delta_{\mathrm{C}} 32.2$ and 29.7. At this point, it was evident that $\mathbf{2}$ and $\mathbf{3}$ should have different stereochemistry. The CD spectroscopy of compounds $\mathbf{2}$ and $\mathbf{3}$ 
Table 1. ${ }^{1} \mathrm{H}$ NMR (500 MHz) spectroscopic data of compounds 1-4 in $\mathrm{CDCl}_{3} . \delta(\mathrm{m}, \mathrm{J} / \mathrm{Hz})$

\begin{tabular}{|c|c|c|c|c|c|}
\hline Position $^{\mathrm{a}}$ & 1 & 2 & 3 & & 4 \\
\hline $1 \alpha\left[1 a^{\prime}\right]$ & $3.08(\operatorname{dd} J 18.0,6.0)$ & $2.44(\operatorname{ddd} J 19.0,8.0,4.5)$ & $2.52(\mathrm{~m})$ & & {$[2.67(\mathrm{br}, \mathrm{d} J 17.0)]$} \\
\hline $1 \beta\left[1 b^{\prime}\right]$ & $2.43(\operatorname{ddd} J 18.0,5.0,1.5)$ & $2.63(\mathrm{dt} J 19.0,8.0)$ & $2.52(\mathrm{~m})$ & $3.80(\mathrm{dd} J 9.0,3.0)$ & {$[2.35(\mathrm{br}, \mathrm{dd} J 17.0,9.0)]$} \\
\hline $2 \mathrm{a}\left[2 \mathrm{a}^{\prime}\right]$ & $5.13(\mathrm{tt} J 6.0,5.0)$ & $1.86(\mathrm{~m})$ & $1.95(\mathrm{~m})$ & $4.78(\operatorname{td} J 9.0,7.0)$ & {$[1.66(\mathrm{~m})]$} \\
\hline $2 \mathrm{~b}\left[2 \mathrm{~b}^{\prime}\right]$ & & $1.86(\mathrm{~m})$ & $1.83(\mathrm{~m})$ & & {$[1.66(\mathrm{~m})]$} \\
\hline $3 \alpha\left[3 a^{\prime}\right]$ & $1.99(\operatorname{ddd} J 14.0,6.0,5.5)$ & $1.81(\mathrm{~m})$ & $1.93(\mathrm{~m})$ & $2.06(\mathrm{~m})$ & {$[1.66(\mathrm{~m})]$} \\
\hline $3 \beta\left[3 b^{\prime}\right]$ & $1.84(\operatorname{ddd} J 14.0,6.0,5.0)$ & $1.91(\mathrm{~m})$ & $1.81(\mathrm{~m})$ & $2.06(\mathrm{~m})$ & {$[1.66(\mathrm{~m})]$} \\
\hline $4\left[4^{\prime}\right]$ & $3.01(\mathrm{qdd} J 7.0,5.5,5.0)$ & & & $3.26(\mathrm{dqd} J 11.0,7.0,3.5)$ & {$[3.01(\mathrm{dqd} J 10.5,7.0,4.0)]$} \\
\hline 12 [12’] & $7.38(\mathrm{q} J 1.0)$ & $7.37(\mathrm{q} J 1.5)$ & $7.35(\mathrm{q} J 1.0)$ & $7.50(\mathrm{q} J 1.5)$ & {$[5.34(\mathrm{~d} J 3.0)]$} \\
\hline 13 [13’] & $2.25(\mathrm{~d} J 1.0)$ & $2.25(\mathrm{~d} J 1.5)$ & $2.24(\mathrm{~d} J 1.0)$ & $2.28(\mathrm{~d} J 1.5)$ & $2.03(\mathrm{~s})$ \\
\hline 14 [14'] & $1.67(\mathrm{~s})$ & $1.91(\mathrm{~s})$ & $1.85(\mathrm{~s})$ & $2.46(\mathrm{~s})$ & $2.50(\mathrm{~s})$ \\
\hline 15 [15'] & $1.42(\mathrm{~d} J 7.0)$ & $1.70(\mathrm{~s})$ & $1.59(\mathrm{~s})$ & $1.25 \mathrm{~d}(7.0)$ & {$[0.92(\mathrm{~d} J 7.0)]$} \\
\hline$-\mathrm{OAc}$ & $2.05(\mathrm{~s})$ & & & & \\
\hline
\end{tabular}

${ }^{\mathrm{a}}$ Arbitrary atom numbering used in the literature. ${ }^{21}$

was comparable with that of cacalone (5), indicating that they have the same stereochemistry at C-6 and, therefore, $\mathbf{2}$ and $\mathbf{3}$ are epimers at C-4. On the other hand, the fact that in compound $2, \mathrm{H}_{3}-14$ and $\mathrm{H}_{3}-15$ resonated at lower field ( $\Delta \delta 0.06$ and 0.11 , respectively) than the same groups in $\mathbf{3}$, indicated that in compound $\mathbf{2}$, each of these methyl groups is feeling a deshielding effect due to its syn orientation with a hydroxyl group, which is not the case in compound $\mathbf{3}$. Additionally, in the carbon resonance of $\mathrm{CH}_{3}-14$ in 3 a downfield shift $(\Delta \delta$ 3.7) was observed with respect to that in $\mathbf{2}$ as a result of a change from a pseudoaxial orientation in compound $\mathbf{2}$ to a pseudoequatorial in $\mathbf{3}$, in order to release steric crowding. ${ }^{20} \mathrm{In}$ the case of $\mathrm{CH}_{3}-15$, this showed almost the same chemical shifts in $\mathbf{2}$ and $\mathbf{3}(\Delta \delta 0.01)$ since it adopted in both pseudoaxial orientation which was $\alpha$ in $\mathbf{2}$ and $\beta$ in $\mathbf{3}$.
This last was evident by the NOESY interaction observed between $\mathrm{H}_{3}-15$ and $\mathrm{H}-1 \alpha$ in compound 2 , and by the coupling in " $\mathrm{M}$ " between $\mathrm{H}_{3}-15$ and $\mathrm{H}-3 \alpha$ observed in the COSY experiment of $\mathbf{3}$. Therefore the absolute configuration of compounds 2 and $\mathbf{3}$ should be $4 S, 6 R$ and $4 R, 6 R$, respectively.

Compound $\mathbf{4}$, obtained as a white amorphous powder, exhibited in the IR spectrum bands of hydroxyl groups $\left(3300 \mathrm{~cm}^{-1}\right)$ and aromatic rings $(1630,1478,1317$, $\left.1113,961 \mathrm{~cm}^{-1}\right)$. The molecular formula $\mathrm{C}_{30} \mathrm{H}_{34} \mathrm{O}_{5}$ was deduced from HRESIMS and in the EIMS, besides the molecular ion peak at $\mathrm{m} / \mathrm{z} 474$, two fragments at $\mathrm{m} / \mathrm{z} 230$ $\left[\mathrm{C}_{15} \mathrm{H}_{18} \mathrm{O}_{2}\right]^{+}$and $245\left[\mathrm{C}_{15} \mathrm{H}_{17} \mathrm{O}_{3}\right]^{+}$indicated the presence of two sesquiterpene moieties. The NMR spectroscopy (Tables 1 and 2) indicated that $\mathbf{4}$ had the same structure as adenostin $\mathrm{B}^{21}(7)$ but bearing an additional hydroxyl group

Table 2. ${ }^{13} \mathrm{C}$ NMR (125 MHz) spectroscopic data of compounds 1-4 in $\mathrm{CDCl}_{3} \delta(\mathrm{m})$

\begin{tabular}{|c|c|c|c|c|c|}
\hline Position $^{a}$ & 1 & 2 & 3 & & \\
\hline 1 [1'] & $27.8(\mathrm{t})$ & $21.2(\mathrm{t})$ & $21.0(\mathrm{t})$ & 36.9 (d) & {$[22.9(\mathrm{t})]$} \\
\hline 2 [2'] & $68.3(\mathrm{~d})$ & $17.8(\mathrm{t})$ & $18.4(\mathrm{t})$ & $61.5(\mathrm{~d})$ & {$[16.3(\mathrm{t})]$} \\
\hline 3 [3'] & $36.6(t)$ & $41.0(\mathrm{t})$ & $39.3(t)$ & $38.9(\mathrm{t})$ & {$[29.6(t)]$} \\
\hline 4 [4'] & 29.8 (d) & $75.5(\mathrm{~s})$ & $74.6(\mathrm{~s})$ & $30.0(\mathrm{~d})$ & {$[28.5(\mathrm{~d})]$} \\
\hline 5 [5’] & $160.0(\mathrm{~s})$ & $155.2(\mathrm{~s})$ & $160.9(\mathrm{~s})$ & $137.8(\mathrm{~s})$ & {$[134.7(\mathrm{~s})]$} \\
\hline $6\left[6^{\prime}\right]$ & $72.1(\mathrm{~s})$ & $72.7(\mathrm{~s})$ & $74.3(\mathrm{~s})$ & $121.7(\mathrm{~s})$ & {$[125.0(\mathrm{~s})]$} \\
\hline 7 [7'] & $140.6(\mathrm{~s})$ & $141.5(\mathrm{~s})$ & $141.7(\mathrm{~s})$ & $127.7(\mathrm{~s})$ & {$[124.2(\mathrm{~s})]$} \\
\hline 8 [8'] & $144.9(\mathrm{~s})$ & $144.6(\mathrm{~s})$ & $144.8(\mathrm{~s})$ & $144.3(\mathrm{~s})$ & {$[144.6(\mathrm{~s})]$} \\
\hline 9 [9'] & $173.8(\mathrm{~s})$ & $174.6(\mathrm{~s})$ & $174.7(\mathrm{~s})$ & $134.2(\mathrm{~s})$ & {$[134.2(\mathrm{~s})]$} \\
\hline 10 [10'] & $128.8(\mathrm{~s})$ & $132.2(\mathrm{~s})$ & $130.2(\mathrm{~s})$ & $118.7(\mathrm{~s})$ & {$[124.5(\mathrm{~s})]$} \\
\hline 11 [11'] & $120.3(\mathrm{~s})$ & $120.3(\mathrm{~s})$ & $120.0(\mathrm{~s})$ & $116.3(\mathrm{~s})$ & {$[89.1(\mathrm{~s})]$} \\
\hline 12 [12’] & 144.8 (d) & $145.0(\mathrm{~d})$ & 144.8 (d) & 141.5 (d) & {$[90.8(\mathrm{~d})]$} \\
\hline 13 [13’] & $8.8(\mathrm{q})$ & $9.0(\mathrm{q})$ & $8.8(q)$ & $11.2(\mathrm{q})$ & {$[26.3(\mathrm{q})]$} \\
\hline 14 [14'] & $26.4(\mathrm{q})$ & $28.5(q)$ & $32.2(\mathrm{q})$ & $13.7(q)$ & {$[12.5(\mathrm{q})]$} \\
\hline 15 [15'] & $21.8(\mathrm{q})$ & $29.6(q)$ & $29.7(\mathrm{q})$ & $20.3(\mathrm{q})$ & {$[20.8(\mathrm{q})]$} \\
\hline \multirow[t]{2}{*}{$-\mathrm{OAc}$} & $170.5(\mathrm{~s})$ & & & & \\
\hline & $21.4(\mathrm{q})$ & & & & \\
\hline
\end{tabular}

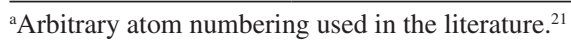


whose gem proton appeared at $\delta_{\mathrm{H}} 4.78$. This proton was identified as $\mathrm{H}-2$ by its correlations with $\mathrm{H}-1$ and $\mathrm{H}_{2}-3$ in the COSY experiment and by its cross peaks observed in the HMBC experiment, with $\mathrm{C}-3$ and $\mathrm{C}-12$. The position of the hydroxyl group was also supported by the deshielding effect in $\mathrm{C}-1(\Delta \delta$ 6.44) and $\mathrm{C}-3(\Delta \delta$ 10.14), as well as the shielding in $\mathrm{C}-12^{\prime}(\Delta \delta-5.61)$, as compared to the corresponding carbon resonances in adenostin B. ${ }^{21}$ The NOESY experiment showed interactions of $\mathrm{H}-12^{\prime}$ with $\mathrm{H}-1$ and $\mathrm{H}_{3}-13^{\prime}$, and of $\mathrm{H}-2$ with $\mathrm{H}_{3}-15$ and $\mathrm{H}-1$, suggesting that they are in the $\beta$ side of the molecule as $\mathrm{H}_{3}-15$, and therefore being indicative of an $\alpha$-orientation the hydroxyl group at C-2.

Structures of the known compounds cacalone (5), ${ }^{6}$ epi-cacalone (6), ${ }^{6}$ adenostin B (7),${ }^{21}$ cacalol (8),${ }^{21}$ cacalol acetate $(\mathbf{9}),{ }^{22}$ cacalohastine $(\mathbf{1 0}),{ }^{23}$ adenostylide $(\mathbf{1 1}),{ }^{24}$ radulifolin $\mathrm{C}(\mathbf{1 2}),{ }^{10}$ radulifolin D (13), ${ }^{9}$ epi-radulifolin $\mathrm{F}$ (14), ${ }^{9}$ hyperin (15) ${ }^{25} \beta$-caryophyllene- $(8 R, 9 R)$-oxide $(\mathbf{1 6}),{ }^{26}$ spathulenol (17), ${ }^{27}$ and caryolane-1,9 3 -diol (18), ${ }^{26}$ were determined by comparison of their physical and spectroscopic features with those reported in the literature. The absolute stereochemistry of cacalone (5) and epi-cacalone (6) has been determined ${ }^{6}$ but, since their CD data were not available in literature, they were obtained in the present work.

The anti-inflammatory activity of the methanolic extracts of roots and aerial parts, and that of compounds 1-4, and 16-18 was evaluated using the TPA model of induced acute inflammation. ${ }^{11}$ Since the anti-inflammatory properties of compounds 5-15 had been previously reported, ${ }^{11,17,18}$ they were not tested in the present work. As shown in Table 3, the extracts exhibited moderate activities (48.14 and $46.76 \%$ for roots and aerial parts, respectively). Compound 4 , with $76.67 \%$ of edema inhibition, was the most active compound showing a dose dependent activity with $\mathrm{IC}_{50} 0.41 \mu \mathrm{mol}$ per ear while that of the reference compound, indomethacin, was $0.24 \mu \mathrm{mol}$ per ear (Table 4).

Table 3. Effect of extracts and compounds 1-4, 16-18 on TPA-induced mouse edema

\begin{tabular}{|c|c|c|c|}
\hline Sample & Dose / ( $\mu$ mol per ear) & Edema / mg & Inhibition / \% \\
\hline Methanolic extract of roots ${ }^{b}$ & $1.0^{\mathrm{a}}$ & $7.53 \pm 1.16^{\mathrm{f}}$ & $48.14^{\mathrm{f}}$ \\
\hline Methanolic extract of aerial parts ${ }^{b}$ & $1.0^{\mathrm{a}}$ & $7.73 \pm 1.07^{\mathrm{f}}$ & $46.76^{\mathrm{f}}$ \\
\hline$(2 R, 4 S, 6 S)$-2-acetoxy-epi-cacalone $(\mathbf{1})^{\mathrm{c}}$ & 1.0 & $5.65 \pm 1.25^{\mathrm{g}}$ & $58.04^{\mathrm{g}}$ \\
\hline$(4 S, 6 R)$-4-hydroxycacalone $(2)^{\mathrm{c}}$ & 1.0 & $5.63 \pm 0.44^{g}$ & $58.17^{\mathrm{g}}$ \\
\hline$(4 R, 6 R)$-4-hydroxycacalone $(3)^{\mathrm{c}}$ & 1.0 & $11.98 \pm 0.81$ & 11.08 \\
\hline $2 \alpha$-hydroxyadesnostin B (4) $)^{\mathrm{d}}$ & 1.0 & $2.80 \pm 0.17^{\mathrm{f}}$ & $76.67^{\mathrm{f}}$ \\
\hline Caryophyllene- $(8 R, 9 R)$-oxide $(\mathbf{1 6})^{\mathrm{d}}$ & 1.0 & $9.63 \pm 0.63$ & 19.72 \\
\hline Spathulenol (17) ${ }^{\mathrm{d}}$ & 1.0 & $8.78 \pm 0.48^{\mathrm{f}}$ & $26.88^{\mathrm{f}}$ \\
\hline Caryolane-1,9ß-diol $(\mathbf{1 8})^{\mathrm{d}}$ & 1.0 & $7.47 \pm 0.37^{\mathrm{f}}$ & $37.78^{\mathrm{f}}$ \\
\hline Indomethacin ${ }^{\mathrm{e}}$ & $1.0^{\mathrm{a}}$ & $2.06 \pm 0.30^{\mathrm{g}}$ & $87.61^{\mathrm{g}}$ \\
\hline Indomethacin ${ }^{\mathrm{e}}$ & 1.0 & $1.99 \pm 0.69^{\mathrm{f}}$ & $83.73^{\mathrm{f}}$ \\
\hline
\end{tabular}

Each value represents the mean of three animals \pm standard error; ${ }^{a}$ dose: mg per ear; control: ${ }^{b}$ methanol, $14.53 \pm 0.38,{ }^{c}$ acetone- $\mathrm{CH}_{2} \mathrm{Cl}_{2} 1: 1,13.47 \pm 0.38$, dacetone- $\mathrm{CH}_{2} \mathrm{Cl}_{2} 1: 1,12.00 \pm 1.50$, eethanol-acetone $1: 1,15.00 \pm 0.47 ;{ }^{\mathrm{f}} \mathrm{p} \leq 0.05 ;{ }^{\mathrm{g}} \mathrm{p} \leq 0.01$.

Table 4. Dose response evaluation of $2 \alpha$-hydroxyadesnostin B (4)

\begin{tabular}{|c|c|c|c|c|}
\hline Sample & Dose / ( $\mu$ mol per ear $)$ & Edema / mg & Inhibition / \% & $\mathrm{IC}_{50} /(\mu \mathrm{mol}$ per ear $)$ \\
\hline Control & & $16.54 \pm 0.34$ & & \\
\hline \multirow[t]{4}{*}{ 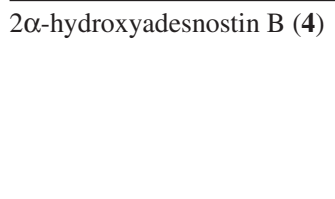 } & 0.031 & $15.74 \pm 0.68$ & 4.84 & 0.41 \\
\hline & 0.1 & $13.34 \pm 0.83^{\mathrm{a}}$ & $19.35^{\mathrm{a}}$ & $\mathrm{r}=0.99$ \\
\hline & 0.31 & $9.34 \pm 1.14^{\mathrm{b}}$ & $43.53^{\mathrm{b}}$ & \\
\hline & 1.0 & $5.12 \pm 0.55^{\mathrm{b}}$ & $69.04^{\mathrm{b}}$ & \\
\hline \multirow[t]{4}{*}{ Indomethacin $^{\mathrm{c}}$} & 0.031 & $12.78 \pm 1.21$ & 13.36 & 0.24 \\
\hline & 0.1 & $10.74 \pm 1.13^{\mathrm{a}}$ & $27.19^{\mathrm{a}}$ & $\mathrm{r}=0.983$ \\
\hline & 0.31 & $5.62 \pm 0.89^{\mathrm{b}}$ & $61.90^{\mathrm{b}}$ & \\
\hline & 1.0 & $2.88 \pm 0.73^{b}$ & $78.76^{\mathrm{b}}$ & \\
\hline
\end{tabular}

Each value represents the mean of five animals \pm standard error; ${ }^{\mathrm{a}} \mathrm{p} \leq 0.05 ;{ }^{\mathrm{b}} \mathrm{p} \leq 0.01 ;{ }^{\mathrm{c}} \mathrm{control} 14.75 \pm 1.13$. 


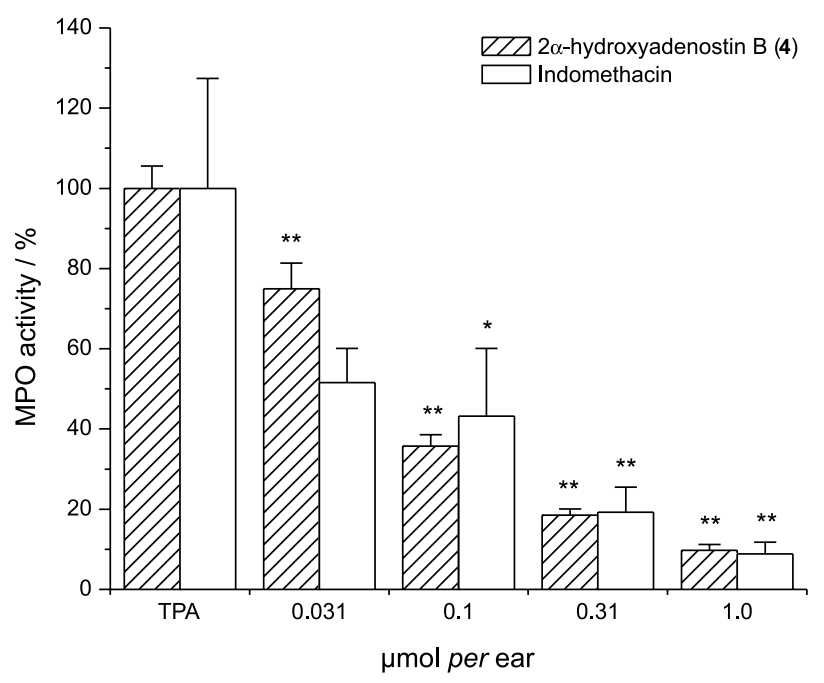

Figure 2. Comparative effect of $2 \alpha$-hydroxyadesnostin B (4) and indomethacin on myeloperoxidase levels in the mouse ear edema induced by TPA. Data represent means \pm standard error of five animals. * $\mathrm{p} \leq 0.05$ and $* * \mathrm{p} \leq 0.01$.

Myeloperoxidase (MPO) is a biochemical marker for tissue content of polymorphonuclear leukocytes because MPO activity is well correlated with the number of infiltrated cells in inflamed regions. ${ }^{28,29}$ In the MPO activity test compound $\mathbf{4}$ attenuated, in a dose-dependent manner, the activity of MPO and showed a similar effect to that of indomethacin at 0.31 and $1.0 \mu \mathrm{mol}$ per ear (Figure 2). The Pearson's correlation analysis between skin weight and the MPO activity of all biopsies of $\mathbf{4}$ showed a positive correlation $(\mathrm{r}=0.83, \mathrm{p}<0.001)$, indicating that edema inhibition of $\mathbf{4}$ is associated with the inhibition of infiltrated neutrophils in the ear biopsy.

\section{Experimental}

\section{General procedures}

Melting points were determined on a Fisher-Johns melting point apparatus and are uncorrected. Optical rotations were determined on a Perkin-Elmer 343 polarimeter. Circular dichroism was obtained on a Jasco J-720 spectropolarimeter. UV and IR spectra were recorded on a Shimadzu UV 160U and a Bruker Tensor 27 spectrometer, respectively. 1D and 2D NMR spectra were obtained on a Varian-Unity Inova $500 \mathrm{MHz}$ spectrometer with tetramethylsilane (TMS) as internal standard. EIMS were determined on a Bruker Daltonics Analysis 3.2 mass spectrometer. HRESIMS were performed on a Bruker micrOTOF II mass spectrometer with mass resolution of $16.500 \mathrm{FWHM}$, mass interval $50-20,000 \mathrm{~m} / \mathrm{z}$, and speed $40 \mathrm{~Hz}$. Column chromatography was carried out under vacuum (VCC) on silica gel G 60 (Merck,
Darmstadt, Germany). Flash column chromatography (FCC) was performed on silica gel 230-400 (MachereyNagel, Germany). Sephadex column chromatography was developed with Sephadex LH 20 (Amersham Pharmacia Biotech AB, Sweden). Analytical TLC was carried out on silica gel $60 \mathrm{GF}_{254}$ or RP-18W/UV 254 (Macherey-Nagel, Germany) and preparative TLC on Si gel $\mathrm{GF}_{254}$ layer thickness $2.0 \mathrm{~mm}$ or RP-18W/UV ${ }_{254}$ layer thickness $1.0 \mathrm{~mm}$.

Plant material

Psacalium cirsiifolium (Zucc.) H. Rob. \& Brettell was collected in Coatepec Harinas, Estado de México, México, in July 2008. A voucher specimen (MEXU 954570) was identified by Dr. José Luis Villaseñor and deposited at the Herbario del Instituto de Biología, Universidad Nacional Autónoma de México.

\section{Extraction and isolation}

Dried and ground roots $(130 \mathrm{~g})$ and aerial parts $(180 \mathrm{~g})$ were macerated separately with $\mathrm{MeOH}$ (three times a day for seven days each) at room temperature. The extract of roots $(15 \mathrm{~g})$ was fractioned by VCC eluted with a hexane-EtOAc-MeOH gradient system. The hexane eluates afforded fraction A. Fraction B was obtained with EtOAc-MeOH 19:1 and fraction C grouped the mixtures obtained with EtOAc-MeOH 9:1 and 4:1. Purification of fraction A $(8.5 \mathrm{~g})$ by VCC eluted with hexaneEtOAc gradient system afforded fractions A1 (hexaneEtOAc 19:1), A2 (hexane-EtOAc 9:1), A3 (hexane-EtOAc 4:1) and A4 (hexane-EtOAc 7:3). Fraction A1 (1.5 g) was purified by VCC, eluted with hexane-EtOAc 49:1, to give cacalol ${ }^{21}(\mathbf{8}, 220 \mathrm{mg})$, cacalol acetate ${ }^{22}(\mathbf{9}, 205 \mathrm{mg})$ and cacalohastine ${ }^{23}(\mathbf{1 0}, 18 \mathrm{mg})$. Fraction A2 $(900 \mathrm{mg})$ produced, after a FCC eluted with hexane-EtOAc 9:1, adenostylide ${ }^{24}(\mathbf{1 1}, 350 \mathrm{mg})$ and $252 \mathrm{mg}$ of a mixture which $(50 \mathrm{mg})$ was purified by preparative RPTLC $\left(\mathrm{MeOH}-\mathrm{H}_{2} \mathrm{O}\right.$ $2: 3 \times 4)$ to obtain cacalone ${ }^{6}(5,12 \mathrm{mg})$ and epi-cacalone ${ }^{6}$ (6, $9 \mathrm{mg}$ ). Fraction A3 (380 mg) was purified by FCC eluted with hexane-acetone 7:3 to obtain fractions A31 and A32. Purification of A31 (100 mg) by preparative RPTLC (MeOH- $\mathrm{H}_{2} \mathrm{O}$ 1:1) produced compounds $1(12 \mathrm{mg})$ and radulifolin $\mathrm{C}^{10}(\mathbf{1 2}, 8 \mathrm{mg})$. Fraction A32 $(48 \mathrm{mg})$ by preparative RPTLC $\left(\mathrm{MeOH}-\mathrm{H}_{2} \mathrm{O} 3: 2 \times 4\right)$ produced compounds $2(10 \mathrm{mg})$ and $\mathbf{3}(8 \mathrm{mg})$. Fraction A4 $(466 \mathrm{mg})$ purified by FCC $(30 \times 2 \mathrm{~cm})$ eluted with hexane-acetone 7:3 followed by preparative RPTLC $\left(\mathrm{MeOH}-\mathrm{H}_{2} \mathrm{O} 1: 1 \times 3\right)$ produced radulifolin $\mathrm{D}^{9}(\mathbf{1 3}, 6 \mathrm{mg})$, adenostin $\mathrm{B}^{21}(\mathbf{7}, 10 \mathrm{mg})$ and compound $4(12 \mathrm{mg})$. Fraction B (2.2 g) purified by VCC eluted with $\mathrm{CH}_{2} \mathrm{Cl}_{2}-\mathrm{MeOH}$ gradient system produced 
a fraction (150 mg obtained with $\mathrm{CH}_{2} \mathrm{Cl}_{2}-\mathrm{MeOH}$ 9:1 mixture) which was submitted to a preparative RPTLC ( $\left.\mathrm{MeOH}-\mathrm{H}_{2} \mathrm{O} 1: 1\right)$ to give epi-radulifolin $\mathrm{F}^{9}(\mathbf{1 4}, 58 \mathrm{mg})$. Fraction $\mathrm{C}(1.2 \mathrm{~g})$ was purified through a sephadex LH 20 column eluted with $\mathrm{MeOH}-\mathrm{H}_{2} \mathrm{O}$ 1:1 to afford hyperin ${ }^{25}$ (15, $30 \mathrm{mg})$. The methanolic extract of the aerial parts $(28 \mathrm{~g})$ was worked out by VCC $(30 \times 10 \mathrm{~cm})$ eluted with EtOAc$\mathrm{MeOH}$ gradient system. Fractions eluted with EtOAc (4.5 g) were purified by VCC eluted with hexane-EtOAc gradient system to yield, from the hexane factions, $\beta$-caryophyllene$(8 R, 9 R)$-oxide ${ }^{26}(\mathbf{1 6}, 45 \mathrm{mg})$ and from the hexane-EtOAc 19:1 eluates a mixture ( $800 \mathrm{mg}$ ) which by FCC eluted with hexane-EtOAc 9:1, produced spathulenol ${ }^{27}(\mathbf{1 7}, 12 \mathrm{mg})$, caryolane-1,9 $\beta-$ diol $^{26}$ (18, $\left.10 \mathrm{mg}\right)$, cacalol $(\mathbf{8}, 180 \mathrm{mg})$, cacalone-epi-cacalone mixture (5 and 6, $250 \mathrm{mg}), \mathbf{1}$ (5 mg), and 4 (9 mg). Fractions eluted with EtOAc-MeOH 4:1 (1.0 g) afforded hyperin(15, $25 \mathrm{mg})$, by purification through a sephadex LH 20 column eluted with $\mathrm{MeOH}-\mathrm{H}_{2} \mathrm{O}$ 1:1.

\section{Evaluation of anti-inflammatory activity}

\section{Animals}

Male NIH mice weighing 25-30 g were maintained in standard laboratory conditions in the animal house (temperature $27 \pm 1{ }^{\circ} \mathrm{C}$ ) in a $12 / 12 \mathrm{~h}$ light-dark cycle, being fed laboratory diet and water ad libitum, following the Mexican official norm MON-062-Z00-1999.

\section{TPA-induced edema model}

The TPA-induced ear edema assay in mice was performed as previously reported, ${ }^{11}$ Tables 3 and 4 .

\section{Myeloperoxidase assay}

Tissue MPO activity was measured in biopsies taken from ears $4 \mathrm{~h}$ after TPA administration using an adapted method of Bradley et al. ${ }^{28}$ and Suzuki et al. ${ }^{29}$ Each mouse ear biopsy was placed in $1 \mathrm{~mL}$ of $80 \mathrm{mmol} \mathrm{L}^{-1}$ phosphate-buffered saline (PBS) pH 5.4 containing $0.5 \%$ hexadecyltrimethylammonium bromide (HTAB). Each sample was homogenized for $30 \mathrm{~s}$ at $4{ }^{\circ} \mathrm{C}$ with a small sample laboratory Tissue Tearor Homogenizer (OMNI International, model 125). The homogenate was freezethawed at room temperature 3 times, sonicated $20 \mathrm{~s}$ and centrifuged at $12,000 \mathrm{rpm}$ for $15 \mathrm{~min}$ at $4{ }^{\circ} \mathrm{C}$. The resulting supernatants $(10 \mu \mathrm{L}$ in quadruplicate) were poured into 96 well microplate and $180 \mu \mathrm{L}$ of $80 \mathrm{mmol} \mathrm{L}^{-1}$ PBS (pH 5.4) without HTAB were added. Microplate was heated at $37{ }^{\circ} \mathrm{C}$ then, $20 \mu \mathrm{L}$ of $0.017 \%$ hydrogen peroxide were added to each well. For the MPO assay, $20 \mu \mathrm{L}$ of $18.4 \mathrm{mmol} \mathrm{L}^{-1} 3,3$ ',5,5'-tetramethylbenzidine in $50 \%$ aqueous dimethylformamide were added to start the reaction. Microliter plates were incubated at $37^{\circ} \mathrm{C}$ for $5 \mathrm{~min}$. The reaction was stopped with $20 \mu \mathrm{L}$ of $2 \mathrm{~mol} \mathrm{~L}^{-1}$ $\mathrm{H}_{2} \mathrm{SO}_{4}$. MPO enzyme activity was assessed colorimetrically using a BioTekMicroplate Reader $(E L \times 808)$ at an absorbance wavelength of $450 \mathrm{~nm}$. MPO activity test results were expressed as percent of the maximal activity, Figure 2.

\section{Statistical analysis}

All data were represented as percentage mean \pm standard error of mean (SEM). The statistical analysis was done by means of Student's t-test, whereas analysis of variance ANOVA followed by Dunnett test were used to compare several groups with a control. $\mathrm{P}$ values $\mathrm{p} \leq 0.05$ and $\mathrm{p} \leq 0.01$ were considered to be significant. Pearson's correlation coefficient was calculated for the edema and MPO results of compound 4 .

\section{(2R,4S,6S)-2-Acetoxy-epi-cacalone (1)}

Colorless oil; $[\alpha]_{\mathrm{D}}^{25}+40.0^{\circ}\left(c 0.08, \mathrm{CHCl}_{3}\right)$; UV $(\mathrm{MeOH}) \lambda_{\max }(\log \varepsilon) 209$ (4.35), 262 (3.06) nm; CD $\left(c 6.6 \times 10^{-5} \mathrm{~mol} \mathrm{~L}^{-1}, \mathrm{MeOH}\right) \Delta \varepsilon_{210 \mathrm{~nm}}-838, \Delta \varepsilon_{226 \mathrm{~nm}}+593$, $\Delta \varepsilon_{263 \mathrm{~nm}}-134$; IR $\left(\mathrm{CHCl}_{3}\right) v_{\max } / \mathrm{cm}^{-1}: 3390,1743,1661$; ${ }^{1} \mathrm{H} \mathrm{NMR}\left(\mathrm{CDCl}_{3}, 500 \mathrm{MHz}\right)$ see Table $1 ;{ }^{13} \mathrm{C} \mathrm{NMR}\left(\mathrm{CDCl}_{3}\right.$, $125 \mathrm{MHz})$ see Table 2; EIMS $m / z 244\left[\mathrm{M}-\mathrm{CH}_{3} \mathrm{COOH}\right]^{+}$ (100), 229 (75), 215 (70); HRESIMS m/z 327.1202 $[\mathrm{M}+\mathrm{Na}]^{+}$(calcd. for $\mathrm{C}_{17} \mathrm{H}_{20} \mathrm{NaO}_{5}, 327.1202$ ).

\section{(4S,6R)-4-Hydroxycacalone (2)}

Colorless oil; $[\alpha]_{\mathrm{D}}^{25}-6.6^{\circ}\left(\right.$ c $\left.0.09, \mathrm{CHCl}_{3}\right)$; UV (MeOH) $\lambda_{\max }(\log \varepsilon) 209$ (3.53), 286 (2.97), 318 (3.23) nm; CD (c $\left.2.7 \times 10^{-4} \mathrm{~mol} \mathrm{~L}-1, \mathrm{MeOH}\right) \Delta \varepsilon_{227 \mathrm{~nm}}-31, \Delta \varepsilon_{254 \mathrm{~nm}}+41$, $\Delta \varepsilon_{280 \mathrm{~nm}}-0.02, \Delta \varepsilon_{316 \mathrm{~nm}}+8$; IR $\left(\mathrm{CHCl}_{3}\right) v_{\max } / \mathrm{cm}^{-1}: 3400$, $1660 ;{ }^{1} \mathrm{H}$ NMR $\left(\mathrm{CDCl}_{3}, 500 \mathrm{MHz}\right)$ see Table $1 ;{ }^{13} \mathrm{C}$ NMR $\left(\mathrm{CDCl}_{3}, 125 \mathrm{MHz}\right)$ see Table 2; EIMS m/z $262[\mathrm{M}]^{+\cdot}$ (8), 244 (12), 229 (100); HRESIMS m/z 269.1356 [M + Li] ${ }^{+}$ (calcd. for $\mathrm{C}_{15} \mathrm{H}_{18} \mathrm{LiO}_{4}, 269.1360$ ).

\section{(4R,6R)-4-Hydroxycacalone (3)}

Colorless oil; $[\alpha]_{\mathrm{D}}^{25}-18.7^{\circ}(c \quad 0.08, \mathrm{MeOH})$; UV $(\mathrm{MeOH}) \lambda_{\max }(\log \varepsilon) 209$ (3.45), 293 (2.83), $317(2.91) \mathrm{nm}$; $\mathrm{CD}\left(c 6.9 \times 10^{-3} \mathrm{~mol} \mathrm{~L}^{-1}, \mathrm{MeOH}\right) \Delta \varepsilon_{220 \mathrm{~nm}}-26, \Delta \varepsilon_{254 \mathrm{~nm}}+0.03$, $\Delta \varepsilon_{273 \mathrm{~nm}}-11 ; \mathrm{IR}\left(\mathrm{CHCl}_{3}\right) \mathrm{v}_{\max } / \mathrm{cm}^{-1}: 3400,1660 ;{ }^{1} \mathrm{H} \mathrm{NMR}$ $\left(\mathrm{CDCl}_{3}, 500 \mathrm{MHz}\right)$ see Table $1 ;{ }^{13} \mathrm{C} \mathrm{NMR}\left(\mathrm{CDCl}_{3}, 125\right.$ $\mathrm{MHz}$ ) see Table 2; EIMS m/z $262\left[\right.$ [M] $^{+\cdot}$ (5), 244 (15), 229 (100); HRESIMS m/z 269.1366 [M + Li] ${ }^{+}$(calcd. for $\left.\mathrm{C}_{15} \mathrm{H}_{18} \mathrm{LiO}_{4}, 269.1360\right)$.

\section{$2 \alpha-$ Hydroxyadenostin B (4)}

White amorphous powder; $[\alpha]_{\mathrm{D}}^{25}-158.3^{\circ}$ ( $c$ 0.13, $\left.\mathrm{CHCl}_{3}\right)$; UV (MeOH) $\lambda_{\text {max }}(\log \varepsilon) 209$ (4.64), 255 (3.88) nm; 
$\mathrm{CD}\left(c 3.8 \times 10^{-5} \mathrm{~mol} \mathrm{~L}{ }^{-1}, \mathrm{MeOH}\right) \Delta \varepsilon_{212 \mathrm{~nm}}-838, \Delta \varepsilon_{230 \mathrm{~nm}}$ $+578, \Delta \varepsilon_{267 \mathrm{~nm}}-111$; IR $\left(\mathrm{CHCl}_{3}\right) v_{\max } / \mathrm{cm}^{-1}: 3300,1630$, 1478, 1317, 1113, 961; ${ }^{1} \mathrm{H}$ NMR $\left(\mathrm{CDCl}_{3}, 500 \mathrm{MHz}\right)$ see Table $1 ;{ }^{13} \mathrm{C} \mathrm{NMR}\left(\mathrm{CDCl}_{3}, 125 \mathrm{MHz}\right)$ see Table 2; EIMS $\mathrm{m} / \mathrm{z}$ 474 [M] $^{+\cdot}$ (15), 245 (40), 230 (100), 215 (45); HRESIMS $m / z$ 497.2294 [M+Na] $]^{+}$calcd. for $\mathrm{C}_{30} \mathrm{H}_{34} \mathrm{NaO}_{5}, 497.2298$ ).

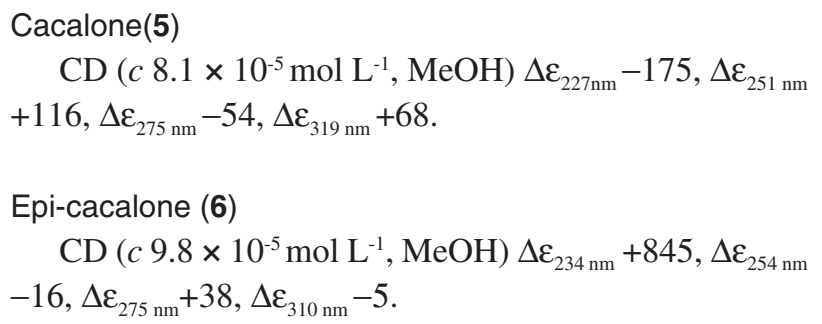

\section{Conclusions}

This study shows that the modified eremophilanes are the main secondary metabolites in Psacalium cirsiifolium in agreement with the chemotaxonomy of the genus Psacalium reported so far. The study of the anti-inflammatory properties of seven of the isolated metabolites, using the TPA-induced mouse edema model, revealed that the new eremophilane derivative $2 \alpha$-hydroxyadenostin B (4) was the most active compound and that this activity is associated with the inhibition of infiltrated neutrophils in the ear biopsy.

\section{Supplementary Information}

Comparative CD of epi-cacalone (6) and compound $\mathbf{1}$, and of cacalone (5) and compounds 2 and 3, ${ }^{1} \mathrm{H}$ NMR spectra of compounds $\mathbf{1 - 7},{ }^{13} \mathrm{C}$ and $2 \mathrm{D}$ NMR experiments of compounds 1-4 are available free of charge at http://jbcs.sbq.org.br as PDF file.

\section{Acknowledgments}

We are indebted to Rubén Gaviño, María Isabel Chávez, Héctor Ríos, Beatriz Quiroz, Ángeles Peña, Elizabeth Huerta, Rocío Patiño, Javier Pérez, Carmen Márquez, Eréndira García and Lizbeth Triana, for technical assistance.

\section{References}

1. Robinson, H.; Brettell, R. D.; Phytologia 1973, 27, 254.

2. Martínez, M.; Las Plantas Medicinales de México, 4a. ed.; Botas: México, 1959, pp. 217-221.

3. Linares, E.; Bye, R.; J. Ethnopharmacol. 1987, 19, 153.
4. Alarcón-Aguilar, F. J.; Jiménez-Estrada, M.; Reyes-Chilpa, R.; González-Paredes, B.; Contreras-Weber, C.C.; Román-Ramos, R.; J. Ethnopharmacol. 2000, 69, 207.

5. Campos,M.G.; Oropeza,M.;Torres-Sosa,C.; Jiménez-Estrada,M.; Reyes-Chilpa, R.; J. Ethnopharmacol. 2009, 123, 489.

6. Inman, W. D.; Luo, J.; Jolad, S. D.; King, S. R.; Cooper, R. J.; J. Nat. Prod. 1999, 62, 1088.

7. Contreras, C.; Román, R.; Pérez, C.; Alarcón, F.; Zavala, M.; Pérez, S.; Chem. Pharm. Bull. 2005, 53, 1408.

8. Alarcón-Aguilar, F. J.; Fortis-Barrera, A.; Angeles-Mejía, S.; Banderas-Dorantes, T. R.; Jasso-Villagómez, E. I.; AlmanzaPérez, J. C.; Blancas-Flores, G.; Zamilpa, A.; Díaz-Flores, M.; Román-Ramos, R.; J. Ethnopharmacol. 2010, 132, 400.

9. Garduño-Ramírez, M. L.; Delgado, G.; Rev. Soc. Quim. Mex. 2003, 47, 160.

10. Garduño-Ramírez, M. L.; Trejo, A.; Navarro, V.; Bye, R.; Linares, E.; Delgado, G.; J. Nat. Prod. 2001, 64, 432.

11. Arciniegas, A.; Pérez-Castorena, A. L.; Nieto-Camacho, A.; Villaseñor, J. L.; Romo de Vivar, A.; J. Mex. Chem. Soc. 2009, $53,229$.

12. Correa, J.; Romo, J.; Tetrahedron 1966, 22, 685.

13. Joseph-Nathan, P.; Negrete, M. C.; González, M. P.; Phytochemistry 1970, 9, 1623.

14. Burgueño-Tapia, E.; Hernández-Carlos, B.; Joseph-Nathan, P.; J. Mol. Struct. 2006, 825, 115.

15. Pérez-Castorena, A. L.; Castro, A.; Romo de Vivar, A.; Phytochemistry 1997, 46, 1297.

16. Pérez-Castorena, A. L.; Arciniegas, A.; Villaseñor, J. L.; Romo de Vivar, A.; Rev. Soc. Quim. Mex. 2004, 48, 21.

17. Jiménez-Estrada, M.; Reyes, C. R.; Ramírez, A. T.; Leidas, F.; Hansberg, W.; Arrieta, D.; Alarcon, A. F.; J. Ethnopharmacol. 2006, 105, 34.

18. Acevedo-Quiroz, N.; Domínguez-Villegas, V.; GarduñoRamírez, M. L.; Nat. Prod. Comm. 2008, 3, 313.

19. Richards, J.; Hendrickson, J.; Biosynthesis of Steroids, Terpenes, and Acetogenins, WA Benjamin, Inc.: New York, 1964, pp. 225237.

20. Kalinowski, H.-O.; Berger, S.; Braun, S.; Carbon-13 NMR Spectroscopy, John Wiley \& Sons: New York, Singapore, 1988, pp. 118-122.

21. Sun, X.-B.; Xu, Y.-J.; Qiu, D.-F.; Yuan, C.-S.; Helv. Chim. Acta 2007, 90, 1705.

22. Bohlmann, F.; Zdero, C.; Phytochemistry 1978, 17, 1135.

23. Hayashi, K.; Nakamura, H.; Mitsuhashi, H.; Phytochemistry 1973, 12, 2931.

24. Kuroyanagi, M.; Naito, H.; Noro, T.; Ueno, A.; Fukushima, S.; Chem. Pharm. Bull. 1985, 33, 4792.

25. Ito, M.; Shimura, H.; Watanabe, N.; Tamai, M.; Hanada, K.; Takahashi, A.; Tanaka, Y.; Arai, I.; Pei-Ling, Z.; Chang, R.; Wei-Ming, C.; Jun-Shan, Y.; Ya-Lun, S.; Yu-Lan, W.; Chem. Pharm. Bull. 1990, 38, 2011. 
26. Heymann, H.; Tezuka, Y.; Kikuchi, T.; Supriyatna, S.; Chem. Pharm. Bull. 1994, 42, 138.

27. Juell, S. M.-K.; Hansen, R.; Jork, H.; Arch. Pharm. 1976, 309 , 458.

28. Bradley, P. P.; Priebat, D. A.; Christensen, R. D.; Rothstein, G.; J. Invest. Dermatol. 1982, 78, 206.
29. Suzuki, K.; Ota, H.; Sasagawa, S.; Sakatani, T.; Fujikura, T.; Anal. Biochem. 1983, 132, 345.

Submitted: June 28, 2012

Published online: February 15, 2013 